\title{
Albanon
}

Revistë kulturore

\section{Gjergj Kastrioti Skënderbeu në këngët popullore}

Ahmet Mehmeti

Figura e ndritur e heroit tonë kombëtar, Gjergj Kastrioti Skënderbeut, zë një vend të spikatur në krijimtarinë shpirtërore të shqiptarëve. Kjo figurë madhore himnizohet në këngët heroike për bëmat dhe sakrificat në emër të lirisë dhe dinjitetit njerëzor, dashurisë së pakufishme për atdheun dhe për trashëgiminë tonë të lavdishme.

Sipas botimeve të derisotme akademike, nga moria e këngëve historike kushtuar Skënderbeut, kemi trashëguar një numër të kufizuar prej 3-4 këngësh të mbledhura kryesisht në rrethin e Krujës, që sipas mendimit të specialistëve, janë këngë në të cilat Skëndebeu kujtohet pas një distance kohe, ndoshta dhe shekullore, pra nuk i takojnë llojit të këngëve të vjetra, të kënduara në kohën e ngjarjeve.

Përkundrazi, në folklorin arbëresh të Italisë, gjenden rreth 8 këngë që lidhen me Skënderbeun dhe luftëtarët e kohës së vet. Varfëria e këngëve në vendlindjen e tij shpjegohet me pushtimin shekullor otoman, i cili nuk lejonte të këndoheshin dhe himnizoheshin bëmat e heroizmat e një luftëtari të lirisë nga më të shquarit e epokës së vet. Siç e vërtetojnë dhe disa autorë të huaj dhe vendas, për Skënderbeun janë krijuar dhe kënduar një numër shumë i madh këngësh, por shumica dërrmuese $u$ harruan dhe nuk $\mathrm{u}$ lejuan, sidomos me islamizimin e hershëm masiv dhe të shpejtë, në zonën qendrore të vendit.

Me islamizimin e vonë dhe jomasiv si dhe me bashkëjetesën e popullsive të të dy besimeve në të njëjtat fshatra e qytete në Çamëri, shpjegohet mbijetesa e disa prej këngëve të vjetra për Skënderbeun në trevën e Çamërisë. Janë katër këngë të vjetra në formën e tyre të plotë, dy motërzime dhe disa fragmente këngësh (rreth tre), si dhe tri legjenda për Skenderbeun, të mbledhura nga goja e shqiptarëve çamë, të ardhur si refugjatë në pjesën brenda kufirit 
shtetëror prej genocidit dhe spastrimit etnik grek me dhunë, nga viti 1913 deri në vitet 1944-1945.

Këto materiale folklorike janë vjelë kryesisht në vitet 50 - 90 të shekullit të kaluar dhe shumica dërrmuese e tyre janë botuar nga folkloristi i shquar Fatos Mero Rrapaj në vëllimet folklorike "Këngë popullore nga Çamëria" (1983) dhe "Rënkimet e Çamërisë" (1995). Është hera e parë që kjo pasuri shumë e çmuar folklorike shqyrtohet, analizohet dhe vlerësohet në këtë shkrim.

Këngë popullore për Skënderbeun janë kënduar edhe nga popujt fqinjë, me admirim për guximin dhe trimërinë e tij dhe të shqiptarëve.

Një nga këngët më të vjetra për Skënderbeun në Çamëri është ajo me titull "Krujë trime n'atë vetull mali". Autori anonim, populli, ka kapur çastin kur heroi ynë sapo ka braktisur kampin otoman të luftës me Magjarinë (Hungarinë) "me treqind thon' tre mil' kalorë". Pastaj kronisti popull raporton për kthimin e Skënderbeut në Krujë, në atdheun e tij të dashur, duke theksuar: “...fushës Dibrës re e zezë ecin, / huadh' Drinin, maleve u qepnë. I S'ka zot thonë që t'u presë udhën, I as ka zot dhe as ka perëndi, / që atire t'u dalë në ballë. I Kualt e tire shkojnë si shigjeta, / të tërbuar vrap që kanë marrë / dhe pehtenjtë flakë u janë dhezur; / "Sulm mbi Krujë!" tha Gjergj Kapedani / dhe teslim me temena Kruja isht bënë."

Pas këtij triumfi të lavdishëm të heroit tonë, bardi popullor na jep me mjeshtëri të lartë artistike, në pesë rreshta të ngjeshur, gjendjen në kampin armik, hidhërimin dhe çoroditjen e sulltanit për sukseset e shpejta në marrjen e kështjellave njëra pas tjetrës: "Ndaj Turqinë e zuri dalldia, I se te bijë zap ajo s'ka kuvet. / Ndaj Sulltan Murati u pezmos: / plasëla i ra kur ai ndjeu / se radhaz Gjergji kalatë ja mori."

Në antitezë me hutimin që kishte pushtuar sulltanin dhe perandorine otomane, lajmi i fitoreve të bujshme të Skënderbeut i ardhur në Janinë, na jepet nga kronikani artist me përmasa sa realiste për të vërtetën po aq hiperbolike për nga shprehja e bukur artistike: "Sihariqi erdhi në Janinë: / se u ka zdrikur Gjergj Kapedani, I me kojdu sa milë kalorë, I në halldupë sla nam e nishan, / nam e nishan s'la në osmanlli. / U mbush bota me gjak të halldupit. / Turku në atë gjak u pllaks. / Ka aj gjak u mbit demi tre vjeç..."

Përballë humbjeve të armikut, bardi popullor na sjell tablonë festive të epirotëve që ditë e net hedhin valle e ndezin zjarre për nder të fitoreve në fushat e betejave. Në këto manifestime marrin pjesë jo vetëm njerëzit, por edhe malet e fushat; zogjtë që fluturojnë në ajër, por edhe gurët e drurët që bëjnë gojë e flasin nga gëzimi që pushton gjithçka: 


\section{Albanon}

\section{Revistë kulturore}

"Ipirotët valle kanë hjedhur,

Dhe çdo natë zjarre kanë dhezur.

Gëzuar u kanë dhe melet e fushat,

Gëzuar u ka dhe Tomorri e Kladhi

Gëzuar u ka Kurilla e Bozhuri

Edhe tërë melet e Janinës

Me at Pindin q'e ka hjen e rëndë,

Na gëzuan edhe zojt e çuar

Edhe gurë e drurë bënë golë e folë,

E i thanë Gjergjit Kapedanit:

"Dhe ne mbret të kemi e të paçim,

Për tani e për tre milë vjet!”

Dhe si për ta mbyllur me një apoteozë këtë tablo madhështore gëzimi universal, autori popullor i bën një thirrje (esklamacion) detit Jon: “Fushë e Zonjës dallgët le t’i hjedhi” duke uruar: "Kushtu thomi e kushtu kloftë bënë?’

Në këtë himn për kthimin e Skënderbeut në Krujë dhe për fitoret e tij të stuhishme radhazi, kundër perandorisë më agresive e më gjakatare të asaj kohe, bie në sy niveli i lartë artistik i tekstit të këngës. Mjeshtëri popullor ka përdorur një seri figurash artistike si: metafora dhe shprehjet metaforike, hiperbola, personifikimi, antiteza, epiteti, krahasimi, esklamacioni etj. Kënga fillon me një thirrje (esklamacion) krenarie:

"Krujë trime, n’atë vetull mali,

Ç’bën e rri ti sot në këtë ditë,

Dil përpara e vëzhdrij atë trim

E pa eja thuaj çili isht aji?

Gjergji it a Skënderbe q'i thone.."

Me një efikasitet të jashtëzakonshëm përdoret metafora, për të karakterizuar Skënderbeun mbi kalë gjatë luftimit me shprehjen "ipje e tërbuar", kalorësit që Fushës së Dibrës "re e zezë ecin”, kuajve "pehtenjtë flakë u janë dhezur", Sulltan Muratit "plasëla i ra kur ai ndjeu se radhaz Gjergji kalatë ja mori; nga gëzimi "edhe gurë e drurë bën golë e folë". 
Një tjetër figurë artistike e përdorur me mjeshtëri të rrallë është personifikimi. Për dorëzimin e Krujës në duart e të zotit, Skënderbeut, thuhet "teslim me temena Kruja isht bënë", ndërkohë që "Turqinë e zuri dalldia”. Të shtatë vargjet që shprehin gëzimin e fitoreve të njëpasnjëshme të Skënderbeut, ku marrin pjesë si qenie të gjalla malet e fushat, zogjtë në fluturim, gurët e drurët që përmendëm më parë, janë shpreje të përsosura metaforike dhe njëkohësisht edhe personifikime me nivel shumë të lartë artistik.

Një forcë të veçantë i jep tekstit të këngës përdorimi i figurës së hiperbolës. Skënderbeut dhe luftëtarëve të tij "S'ka zot thonë që t’u presë udhën, I as ka zot dhe as ka perëndi, / që atire t’u dalë në ballë’. Për të treguar kërdinë që bëri Skënderbeu mbi turqit, përdor shprehjet hiperbolike “...në halldupë s'la nam e nishan, / nam e nishan s'la në osmanlli..." dhe "U mbush bota me gjak të halldupit. / Turku në atë gjak u pllaks / Ka aj gjak u mbit demit re vjeç..."

Me shumë precizion është përdorur dhe krahasimi për sulmet e befta të kalorësve: "Kualt e tire shkojnë si shëgjeta" ose përdorimin e epitetit duke e vënë para emrit për t’i dhënë forcë maksimale si në rastin “të tërbuar vrap që kanë marrë".

Përveç vlerës si vepër artistike, kjo këngë ka vlera të jashtëzakonëshme folklorike si këngë e vjetër burimore për disa arsye. Na jepet në 49 vargje të bardha (pa rimë) dhjetërrokëshe të sistemit tonik si në këngët legjendare dhe të kreshnikëve, në njëshkolonë. Ka raste kur mjeshtri i madh popull, si gjeniu Shekspir, përdor edhe rimën për të theksuar një çast të jashtëzakonshëm, si figurativisht edhe emocionalisht: "edhe gurë e drurë bën golë e folë".

Pjesë e ngjarjeve dhe e emocioneve bëhen edhe elementet e natyrës, malet e fushat, zogjtë në ajër, guri e druri. Në të pëshkruhet figura e Skënderbeut në veprim e sipër, në lëvizje të vazhdueshme, nëpër beteja, "mbali kalit, ipje e tërbuar, I fusha e male aj i kapëton, I rëpara kah Kruja shkon”. I gjithë teksti ka një rrjedhë historike, pa mbivendosje tekstesh të mëvonëshme. Vjetërsia e kësaj kënge vërehet edhe në brendinë dhe termat e përdorura, sidomos emërtimet e vendeve si Magjaria për Hungarinë dhe Ipero për Epirin etj.

Për nga niveli i lartë artistik i kësaj kryevepre të folklorit shqiptar për heroin tonë kombëtar, Skënderbeun, për rëndësinë e saj si dokument artistik dhe historik njëkohësisht, do t’ia vlente shumë që të përfshihej në tekstet e folklorit të shkollave të mesme e të larta në Shqipëri dhe kudo në trojet tona etnike.

Në këngën që fillon me vargun “Skënderbeu mjekërglatë" bie në sy ndërtimi i përmbajtjes së saj nëpërmjet figurës së antitezës. Nga njëra anë kemi heroin 


\section{Albanon}

\section{Revistë kulturore}

tonë, "Skënderbeu me trimëri, / me di milë suvari?", që po vjen nga Dibra dhe ka sjellë urdhërin nëpërmjet tellallit: "Të futet bërna asqeri / se turqet $u$ erth exheli”, ndërkohë që në këngë shfaqet madhështor "Skënderbeu përmbi at, / palla e tija këllon gjak" dhe nga ana tjetër kemi sulltanin shkretan që çirret e bërtet me inat: “Skënderbeu, lanet pastë, / na bëri zemrën farmak?' Në vijim kënga shpalos fitoret në kështjellat e Petrelës, Beratit e me radhë deri në Janinë:

Vate haberi Petrelë:

"Priti pasha se të erdhë."

Vate haberi Berat:

"Skënderbeu mjekërglatë,

Për turqit u bë kasap!"

Vate haberi Janinë:

"Skënderbeu u zdrik n'Ipirë."

Dhe më në fund bardi popullor del me përfundimin triumfues e njëkohësisht ironizues e përbuzës:

"O sulltan, o kokëlibë,

Keq seç' të zunë dallditë?’

Krejt ndryshe na vjen deri në ditët tona kënga “Mos na pe ti Gjergjin tënë?”. Kjo këngë e merr subjektin e vet legjendar nga koha kur Gjergji ka qenë peng në Stamboll. Nëna i drejtohet hënës nëse ka parë katër djem të humbur. Hëna i tregon se atyre u premtuan dituri, grada të larta, kuaj me shala e frerë të arta, shpata të argjendta dhe për gra do t'u jepnin "më të mirat në Turqi, të bukurat si perri” me kusht që të bëheshin turq. Tre prej tyre që nuk deshën "me cohë pa mëngë i veshën", pra i vranë. Pasi kaloi një kohë e gjatë :

Një natë që kish dalë hëna

Del prapë nënë grikëzëna:

- Hënё, o moj ti hënё

Që na ndriçon vëndë

Atej kaha ke klënë

Mos na pe Gjergjin tënë? 
Edhe hëna seç $i$ thotë:

- E paçë, çi nuk e paç,

Ja atje e paçë sot

Me pesqint iperotë

Të hipur mi kual,

Me shpata në duar

Vinë dikue kënduar

Siç duket edhe kjo këngë, pavarësisht elementeve legjendare, në esencë evokon të vërtetën historike të kthimit të Skënderbeut në atdhe si çlirimtar. Shprehja "me pesqint iperotë" dëshmon se kemi të bëjmë me një këngë të vjetër kur shqiptarët identifikoheshin me këtë emër.

Një tjetër këngë që na vjen në dy motërzime dhe në një variant të përpunuar, duket qartë se ka shtresëzime gjuhësore të reja ose ka përpunime dhe elemente të toponomastikës si Ballkan dhe Shqipëri. Rrjeshti i parë është "Ka vjen ti, o trim?" Po japim motërzimin e parë të plotë:

- Ka vjen ti, o trim, Trim, o kapetan?

- Vi ka ushtëria' ka mali Ballkan!

- As pe Skënderbejnë, trim, o kapetan,

mbren e Shqipërisë Skëndebejn' me nam?

- U at' e pashë

Kur hidhej në zjarr

Në luftë me Turqinë

E keshë kumandar!

Tani aj ka vdekur

Po turkun s'e la

Jaram buzë varrit

Skënderbeu s'ju nda. 


\section{Albanon}

\section{Revistë kulturore}

Në motërzimin e dytë kënga na vjen në këtë formë më të shkurtuar:

- Ka na vjen, o trim,

trim e kapetan?

-Ka mal' i Mursisë,

ka malet Ballkan

ka mbret' i Shqiprisë

Skënderbeu me nam!

Mbartësit e dy motërzimeve janë njëri nga Kastriza dhe tjetri nga Vërsela. Përdorimi i emërvendeve, siç u përmend më parë, Shqipëri dhe Ballkan, dëshmon për një zgjim të ndjenjës kombëtare që arriti kulmin gjatë periudhës së Rilindjes Kombëtare, dy shekuj më parë.

Interesante është të shtojmë këtu një dukuri që na sjell në librin e tij të kohëve më të fundit shkrimtari i mirënjohur Hyjni Ceka që titullohet "Dita e Verës” (2018) me biografi të letrarizuara, tregime dhe ese. Autori na sjell një variant të tretë të kësaj kënge, të cilës këngëtari i shquar Isuf Myzyri në fund të viteve ' 30 dhe fillim të viteve " 40 , sipas prirjeve të kohës, "i veshi” një melodi origjinale, e cila bëri që kënga të përhapet më shumë gjithandej:

- A e njeh, or ti, trim o kapedan

Mbretin e Shqipërisë, Skënderbenë me nam?!

- Unë e njoh fort mirë burrin e vërtetë...

Se për Shqipërinë trim i madh ka vdekë...

Kjo dukuri dëshmon qartë për mekanizmat e shtimit të popullaritetit të këngëve dhe përhapjes së tyre të shpejtë sipas idealeve social-kulturore të epokave përkatëse.

Eshtë vendi këtu të bëjmë një krahasim me këngët popullore të kombeve të tjera fqinje me ne, shqiptarët. Në një këngë popullore serbe ku i këndohet me admirim Skënderbeut dhe që është botuar në vitin 1883 në Pançevo, në librin "Skënderbeu në këngë" thuhet:

Nëse mendon Epirin ta robërosh,

Skënderbeun gjallë ta zesh,

Merr pesëdhjetë mijë ushtarë,

Sepse ti nuk e di çka janë shqiptarët: 
Njëri do t'u hidhet njëqindëve

Skënderbeu do t’u hidhet njëmijëve.

Përveç admirimit për energjinë e pashtershme të shqiptarëve dhe kryeheroit të tyre, në këtë këngë bien në sy elemente thelbësore për identifikimin e tyre si të tillë, me fuqi titanike kundër robërisë. Ndryshe nga historiografia nacionaliste që vazhdon të vegjetojë edhe sot në disa qarqe akademike fqinje, por edhe te disa pseudohistorianë e pseudopublicistë shqiptarë, në këtë këngë me vlera të shkëlqyera emri i atdheut të Skëndebeut quhet Epir (ose dhe Arbania, si shtresëzim i mëvonshëm), ashtu siç e përmend ai vetë në letërkëmbimin e tij si dhe biografi kryesor i tij, Marin Barleti. Në këtë këngë shqiptarët quhen qartë arbanasi. Kënga popullore serbe është ndërtuar me varg dhjetërrokësh, ngjashëm me këngët sllavojugore të ciklit të kreshnikëve dhe me një ritmikë të gjallë e të fuqishme si vetë subjekti të cilit i këndon. Nga termat si dhe nga elementet e metrikës, kjo këngë shumë interesante dëshmon për një krijim folklorik të kohës së Skënderbeut, për nga lashtësia e saj. Për nga bukuria e tingëllimit po sjellim më poshtë dy vargje origjinale të saj:

\section{Ako mislish Epir porobiti \\ Skenderbega zhiva uhvatiti...}

Epokës së Skënderbeut, në folklorin e trevës së Çamërisë i takojnë edhe dy fragmente këngësh; njëra me titull “Gjino Vat o, Gjino Vat”, një trimi që ka luftuar nën komandën e heroit tonë kombëtar, nga Grikohori i Çamërisë, dhe tjetra me titull "Se Berat, se Berat" ku një vajzë me emrin Mara i këndon fitores së betejës së Skënderbeut mbi turqit, kur ky shtiu në dorë kështjellën e Beratit.

Një perlë e folklorit shqiptar të periudhës pas vdekjes së heroit tonë, që i ka mbijetuar kohës, është Kënga e Gjorg Golemit e cila edhe sot këndohet në trevat e Rrajcës, Bërzeshtës, Sopotit, Polisit e Shpatit dhe na ringjall krenarinë dhe vijimësinë e heroizmave skënderbegiane:

Ky sulltani qan me lot:

"Kam dhe një Skënder në Sopot!

në Mal Plak, më një breg

Gjorg Golemi thotë jam mbret!

Në Mal Plak e në Sopot

Gjorg Golemi kryezot!" 


\section{Albanon}

\section{Revistë kulturore}

Kjo vendosmëri për mbrojtjen e lirisë nuk mund të shprehet më bukur seç e ka shprehur bardi popullor:

Sopotare, moj të ngrata

rrokni thika, rrokni shpata!

A do ikim të shpëtojmë,

a do rrimë të lëftojmë?

-Na do rrimë të lëftojmë

Gjorg Golemin s’e turpërojmë.

Përveç këngëve, në Çamëri ka edhe tri legjenda që lidhen me Skënderbeun dhe luftën çlirimtare të ushtrive të tij në territoret e saj, pikërisht në majat e larta Flamuri i Madh dhe Flamuri $i$ Vogël të Malit të Bozhurit. Po kështu flitet se çamët në përkujtim të vdekjes së Skënderbeut e kanë mbajtur festen e bardhë (plisin), në pjesën e sipërme, të shtypur si përrua, si varr i hapur në shenjë zie dhe nderimi për heroin e tyre. Ndërkohë gratë e krishtera çame të Gumenicës dhe fshatrave përqark, mbajnë edhe sot një rrip të zi, të lidhur në ballë, mbi shaminë e zezë si shenjë nderimi e përkujtimi për vdekjen e Skënderbeut.

Megjithëse kanë kaluar pesë shekuj e gjysëm, mbartësit e këtyre këngëve e legjendave kanë ruajtur me dashuri të jashtëzakonëshme në mendje e në zemër jehonën e gjallë të bëmave herioke të kryeheroit tonë kombëtar, Gjergj Kastriot Skënderbeut, pavarësisht besimeve fetare. Vlerat e larta artistike të këtyre perlave të folklorit tonë gojor na vijnë nga thellësia e shekujve duke na sjellë jo vetëm jehonën e heroizmit, por edhe emocionet e një arti me vlera të larta të artistëve popullorë. Kështu kënga e parë, me titull "Krujë trime n'atë vetull mali” është mbledhur në vitin 1960 nga Jasin Brahimi (dtl.1913) nga fshati Mazrrek i Margëlliçit, refugjat i vitit 1944 me banim në Vlorë. Kënga "Skënderbeu mjekrglatë" është marrë nëpërmjet veprimtarit të shquar Musa Demi (dtl.1878) prej Filatit nga atdhetari Miho Tasi, çam nga fshati Kastri i Gumenicës, shok i ngushtë i Musait dhe publicistit Salih Çeka, anëtar i Klubit të Filatit dhe nëpunës në qeverinë e Ismail Qemalit.

Kënga “Mos na pe ti Gjergjin tënë?” është mbledhur nga çamët refugjatë të hershëm në Sopik të Sarandës nga Fatos M. Rrapaj (dtl. 1928) si edhe një variant të përafërt me këtë edhe në dy fshatrat e krishtera shqiptare të Dropullit, në Frashtan dhe Lugar, nga goja e së moshuarës Leno Lici. 
Përsa u takon varianteve të këngës "Ka vjen ti, o trim”, të parin e kemi nga Kostë Jorgo Thanasi, i ati i atdhetarit Taso Dhima (Anastas Kosta Jorgo Thanasi) nga fshati Kastri i Gumenicës. Variantin e dytë të kësaj kënge e ka dëgjuar autori (A. M.) i këtij shkrimi në fillim të viteve '60 nga gjyshi i tij, Beqir Mustafa Mehmeti (dtl. 1881) nga fshati Vërselë i Filatit, refugjat i vitit 1944, me banim në Valas të Elbasanit.

Fakti që këngët historike për Skënderbeun janë kënduar dhe ruajtur deri në ditët tona, nga shqiptarët pa dallime fetare, dëshmon jo vetëm për karakterin e drejtë të luftrave të tij çlirimtare, por edhe për unitetin kombëtar të shqiptarëve si dhe për bukurinë dhe forcën artistike të krijimeve folklorike të këtij kombi me vlera të mëdha në mes të Europës.

\section{BIBLIOGRAFIA}

Fatos M. Rrapaj, 1983, Këngë popullore nga Çamëria, Tiranë, f. 435-437

Fatos M. Rrapaj, 1995, Rënkimet e Çamërisë, Tiranë, f. 47-49

Fraçesko Altimari, 1980, Mbi figurën e Skënderbeut në letërsinëgojore arbëreshe.

Studime Filologjike, 2/1980 f.73 - 80 si dhe Çështje të Folklorit Shqiptar I, Tiranë, f. 278 - 386.

Gjergj Zheji, 1999, Folklori Shqiptar, Tiranë, f. 198 - 216

Hyjni Ceka, 2018, Dita e verës Tiranë, f. 38 - 39.

Jeronim de Rada, 1866, Rapsodi të njëpoeme shqiptare në Mbledhës të Hershëm të Folklorit I, 1961, Tiranë, f. 119 - 201

Skenderbeg u pesmama, 1883, Pançevo, f. 9-11 